\title{
Bioefficacy, Phytotoxicity and Economics of Post-emergence Herbicides in Moth Bean (Vigna aconitifolia) in Hot Arid Regions
}

N.K. Jat, D.V. Singh

10.18805/LR-4776

\begin{abstract}
Background: Weed infestation is the major cause of yield loss to Kharif pulses in arid regions. Post-emergence herbicide application is a promising weed management option for pulses in these areas. Therefore, the current study was aimed to find an effective and economic post-emergence herbicide molecule for weed control in moth bean.

Methods: A field experiment was conducted during 2017-2019 with different herbicides, hand weeding, weed-free and unweededs in Kharif mung bean in a randomized complete block design with three replications.

Result: Among the herbicide treatments, post-emergence application of propaquizafop + imazethapyr @ $125 \mathrm{~g}$ a.i. ha ${ }^{-1}$ being statistically at par with clodinafop-propargyl + sodium acifluorfen @ $312.5 \mathrm{~g}$ a.i. ha ${ }^{-1}$ and hand weeding recorded the highest reduction in total weed dry matter $(73.9 \%)$, highest weed control efficiency $(73.8 \%)$ and lowest weed persistence index (1.03) compared to the unweeded. The reduction in seed yield in unweeded compared to weed-free and hand weeding was $50.8 \%$ and $42.1 \%$, respectively. As the imazethapyr-containing herbicides caused crop phytotoxicity, significantly higher crop dry weight $\left(513 \mathrm{~g} \mathrm{~m}^{-2}\right)$, seed yield $(5.53 \mathrm{q}$ ha-1), stover yield $\left(18.0 \mathrm{q} \mathrm{ha}^{-1}\right)$, gross returns and net benefits of moth bean were recorded with clodinafop-propargyl + sodium acifluorfen (312.5 g a.i. ha ${ }^{-1}$ ) over other herbicide treatments. Clodinafop-propargyl + sodium acifluorfen (@312.5 g a.i. ha $\left.{ }^{-1}\right)$ registered the $^{-}$ minimum value of weed index (20) and highest values of herbicide efficiency index (3.9) and crop resistance index (4.70).

Key words: Herbicide phytotoxicity, Imazethapyr, Weed persistence, Weed interference, Weed index.
\end{abstract}

\section{INTRODUCTION}

Moth bean [Vigna aconitifolia (Jacq.) Marechal] is a most drought tolerant rainy season legume grown extensively in arid and semi-arid regions of India. Rajasthan, followed by Gujarat, has the highest area $(98.25 \%)$ and production $(97.04 \%)$ of moth bean in the country (Patel et al., 2019). However, in western Rajasthan's weed infestation is the major impediment for acreage and productivity of moth bean (Jat et al., 2011). Depending upon the intensity and type of weed flora, weed infestation in moth bean causes a yield loss to the extent of $75 \%$ (Saxena et al., 2003). Hence, practical and economical weed control is the best management practice for enhancing the productivity of moth bean.

Over the years, herbicidal weed control in pulses has emerged as a promising solution. Furthermore, considering the limitations of pre-emergence herbicides (Punia et al., 2011), post-emergence (PoE) herbicide application provides better weed management options for farmers (Rashid et al., 2009). Because of its high herbicidal activity and broadspectrum weed control, imazethapyr is emerging as a potent PoE herbicide for Kharif pulses (Singh et al., 2016). However, other researchers also suggested higher weed control efficiency of clodinafop-propargyl + sodium-acifluorfen combination against imazethapyr in mungbean (Harithavardhini et al., 2016). In rainfed conditions, herbicide application generates stress even into tolerant crops and cultivars, manifesting crop phytotoxicity. Hence, before recommendation for broader use, suitable herbicide molecules should be evaluated for their phytotoxic effects
ICAR-Central Arid Zone Research Institute, Jodhpur-342 003, Rajasthan, India.

Corresponding Author: N.K. Jat, ICAR-Central Arid Zone Research Institute, Jodhpur-342 003, Rajasthan, India.

Email: nandagro09@gmail.com

How to cite this article: Jat, N.K. and Singh, D.V. (2021). Bioefficacy, Phytotoxicity and Economics of Post-emergence Herbicides in Moth Bean (Vigna aconitifolia) in Hot Arid Regions. Legume Research. 44(12): 1488-1492. DOI: 10.18805/LR-4776.

Submitted: 27-08-2021 Accepted: 26-10-2021 Online: 06-11-2021

and weed control efficacy in a particular agro-climatic region. Therefore, the present research was carried out to find the effectiveness of different post-emergence herbicides in moth bean under arid conditions of western Rajasthan.

\section{MATERIALS AND METHODS}

A field experiment was conducted at ICAR-Central Arid Zone Research Institute, Jodhpur $\left(27^{\circ} 18^{\prime} \mathrm{N}\right.$ latitude and $73^{\circ} 01^{\prime} \mathrm{E}$ longitude) from 2017 to 2019 . The experimental field was well-drained with loamy sand soil low in organic carbon $(0.18 \%)$ and available nitrogen $\left(170 \mathrm{~kg} \mathrm{ha}^{-1}\right)$, medium in available phosphorous (16.8 $\left.\mathrm{kg} \mathrm{ha}^{-1}\right)$ and potassium (277 $\left.\mathrm{kg} \mathrm{ha}^{-1}\right)$ with slightly alkaline in reaction $(\mathrm{pH} 8.3)$. The region's average annual rainfall is about $365 \mathrm{~mm}$, mainly received during the rainy season.

Eleven treatment combinations comprising preemergence and post-emergence herbicides along with hand weeding, weed-free and unweeded were applied in Kharif 
moth bean (Table 1). The experiment was laid out in randomized block design with three replications keeping the plot size $5 \mathrm{~m} \times 3 \mathrm{~m}$. The herbicides were sprayed with a knapsack sprayer fitted with a flat fan nozzle using a water volume of $500 \mathrm{I} \mathrm{ha}^{-1}$.

The rainfed moth bean was sown during the first fortnight of July and harvested in the second fortnight of September. Moth bean 'CAZRI Moth-2' $12 \mathrm{~kg} \mathrm{ha}^{-1}$ was planted at $30 \mathrm{~cm}$ row spacing with the help of a seed drill. The recommended dose of fertilizers (10 kg N + $20 \mathrm{~kg} \mathrm{P}$ ) was applied as basal through urea and DAP. The crop was managed uniformly throughout the growth period, except for weed control.

Observations on weed infestation were recorded after harvest of crops with a quadrate of $0.5 \times 0.5 \mathrm{~m}\left(0.25 \mathrm{~m}^{2}\right)$ size placed at two randomly selected places in each plot, leaving an area of $30 \mathrm{~cm}$ from the plot borders. Weed density (no. $\mathrm{m}^{-2}$ ) was recorded by categorizing the sampled weeds into grasses, broad-leaved and sedges. For recording dry matter of weeds $\left(\mathrm{g} \mathrm{m}^{-2}\right)$, the categorized weeds were first air-dried for five days and then oven-dried at $65 \pm 5^{\circ} \mathrm{C}$ until constant dry weight ( $\sim 8 \mathrm{hrs})$. Phytotoxicity of herbicides was recorded at 10 days after application on a $0-10$-point visual score scale as suggested by Rao (2000).

The crop dry weight was recorded from five randomly selected plants from each plot just before harvesting. Seed yield and stover yield $\left(\mathrm{kg} \mathrm{ha}^{-1}\right)$ were recorded based on the yield obtained from the net plot $(2 \mathrm{~m} \times 3 \mathrm{~m})$. Economics was computed based on prevailing market prices of products and inputs. Weed control efficiency (WCE) and weed index (WI) were calculated by using the standard formula suggested by Mani et al. (1973). Impact indices, viz. weed persistence index (WPI), crop resistance index (CRI) and herbicide efficiency index (HEI), were worked out as per Sen et al. (2020).

The collected data for weed and crop parameters were statistically analyzed separately using SPSS (version 16.0). Before statistical analysis, the weed density and dry weed weight data were subjected to square root transformation $\left[(x+0.5)^{1 / 2}\right]$. Data analysis was done through analysis of variance using the F-test. Means were separated at a $5 \%$ level of significance as per Tukey's honest significant difference test.

\section{RESULTS AND DISCUSSION Weed interference}

In terms of weed flora composition, grassy weeds were dominant, constituting about $39.6-65.3 \%$ of total weed density across the treatments, followed by broad-leaved weeds (26.3-46.6\%) and sedges (6.3-28.2\%). However, in terms of total weed dry matter, across the treatments dominating group was broad-leaved weeds (56.7-71.3\%), followed by grassy weeds (20.7-35.4\%) and sedges (4.413.6\%) (Table 2).

Weed density and dry matter at harvest differed significantly among the weed management practices (Table 2). Among the herbicide treatments, propaquizafop + imazethapyr (PoE $125 \mathrm{~g}$ a.i. ha $\left.{ }^{-1}\right)\left(T_{5}\right)$, being at par with other imazethapyr treatments $\left(T_{2}, T_{3}\right.$ and $\left.T_{4}\right)$ and hand weeding $\left(T_{9}\right)$, recorded significantly lower total weed density $\left(21.3 \mathrm{~m}^{-2}\right)$. The lowest per cent reduction in total weed dry matter compared to unweeded was recorded under clodinafop-propargyl + sodium acifluorfen @ 187.5 g a.i. ha ${ }^{-1}$ $\left(\mathrm{T}_{6}\right)(41.6 \%)$. The imidazolinones herbicides (imazethapyr and imazamox) are absorbed both by the roots and the shoots (Saltoni et al., 2004); hence, imazethapyr in combination with propaquizafop provided wide spectrum weed control and resulted in lesser weed counts and produced lower weed dry matter. These findings are in line with Khairnar et al. (2014).

Application of clodinafop-propargyl + sodium acifluorfen both at $250 \mathrm{~g}$ a.i. ha-1 $\left(\mathrm{T}_{7}\right)$ and $312.5 \mathrm{~g}$ a.i. ha-1 $\left(\mathrm{T}_{8}\right)$ also led to weed dry matter suppression at par to imazethapyr treatments $\left(T_{2}, T_{3}, T_{4}\right.$ and $\left.T_{5}\right)$ and hand weeding $\left(T_{9}\right)$. Minimum weed density and weed dry matter under propaquizafop + imazethapyr (PoE $125 \mathrm{~g}$ a.i. ha- $\left.{ }^{-1}\right)\left(T_{5}\right)$ are presumably due to effective control of grassy and broadleaf weeds, especially at the early growth stages. Further, clodinafoppropargyl + sodium acifluorfen @ 312.5 g a.i. ha-1 $\left(\mathrm{T}_{8}\right)$

Table 1: Weed control treatments, rate and time of application in moth bean.

\begin{tabular}{|c|c|c|c|}
\hline Treatment & Weed management practice & Rate of application (a.i. ha ${ }^{-1}$ ) & Time of application \\
\hline $\mathrm{T}_{1}$ & Pendimethalin & $750 \mathrm{~g}$ & 1 DAS \\
\hline $\mathrm{T}_{2}$ & Imazethypr & $50 \mathrm{~g}$ & 20 DAS \\
\hline $\mathrm{T}_{3}$ & Imazethapyr + imazamox (Pre-mix) & $60 \mathrm{~g}(35 \mathrm{~g}+25 \mathrm{~g})$ & 20 DAS \\
\hline $\mathrm{T}_{4}$ & Propaquizafop + imazethapyr (Pre-mix) & $100 \mathrm{~g}(40 \mathrm{~g}+60 \mathrm{~g})$ & 20 DAS \\
\hline $\mathrm{T}_{5}$ & Propaquizafop + imazethapyr & $125 \mathrm{~g}(50 \mathrm{~g}+75 \mathrm{~g})$ & 20 DAS \\
\hline $\mathrm{T}_{6}$ & Clodinafop-propargyl + sodium acifluorfen (Pre-mix) & $187.5 \mathrm{~g}(61.9 \mathrm{~g}+125.6 \mathrm{~g})$ & 20 DAS \\
\hline $\mathrm{T}_{7}$ & Clodinafop-propargyl + sodium acifluorfen & $250 \mathrm{~g}(82.5 \mathrm{~g}+167.5 \mathrm{~g})$ & 20 DAS \\
\hline $\mathrm{T}_{8}$ & Clodinafop-propargyl + sodium acifluorfen\# & $312.5 \mathrm{~g}(103.1 \mathrm{~g}+109.5 \mathrm{~g})$ & 20 DAS \\
\hline $\mathrm{T}_{9}$ & Hand weeding (Farmers' practice) & Once & 25 DAS \\
\hline $\mathrm{T}_{10}$ & Unweeded & - & \\
\hline $\mathrm{T}_{11}$ & Weed-free check (hand weeding) & Thrice & - \\
\hline
\end{tabular}

DAS= Days after sowing, a.i.= Active ingredient; \#Applied during 2018 and 2019 only. 
Bioefficacy, Phytotoxicity and Economics of Post-emergence Herbicides in Moth Bean (Vigna aconitifolia) in Hot Arid Regions

also caused effective weed control and led to $66.3 \%$ and $73.3 \%$ reductions in total weed density and total weed dry matter over unweeded $\left(\mathrm{T}_{10}\right)$. A narrow-spectrum activity against weeds (Table 2 ) rendered clodinafop-propargyl + sodium acifluorfen less effective at lower doses $\left(T_{6}\right.$ and $\mathrm{T}_{7}$ ). However, clodinafop-propargyl + sodium acifluorfen (@ $312.5 \mathrm{~g}$ a.i. ha $\left.{ }^{-1}\right)\left(\mathrm{T}_{8}\right)$ could cause sufficient growth suppression and found at par with imazethapyr treatments in weed dry matter reduction. Harithavardhini et al. (2016) reported higher efficacy of clodinafop-propargyl + sodium acifluorfen over imazethapyr in mung bean.

\section{Crop phytotoxicity}

The phytotoxicity rating of applied herbicides on crop growth revealed that PoE application of imazethapyr-containing herbicides $\left(T_{2}, T_{2}, T_{4}\right.$ and $\left.T_{5}\right)$ caused a phytotoxic effect (score 1-2) on moth bean. The phytotoxic effect of herbicides caused stunting and discolouration of leaves which persisted up to flowering and reflected on the final yield of the crop as well (Table 3 ). Similar results of imazethapyr phytotoxicity were reported earlier by Punia et al. (2015) on mung bean.

\section{Crop growth and yield}

The favourable growth environment in weed-free $\left(T_{11}\right)$ treatment resulted in the significantly highest crop dry weight $\left(613 \mathrm{~g} \mathrm{~m}^{-2}\right)$, seed yield $\left(6.92 \mathrm{q} \mathrm{ha}^{-1}\right)$ and stover yield (23.9 q ha-1) over other treatments (Table 3 ). On the other hand, the reduction in seed yield in unweeded compared to weedfree and hand weeding was $50.8 \%$ and $42.1 \%$, respectively. These results are in agreement with as reported by Upadhayay et al. (2013). Moreover, clodinafop-propargyl + sodium acifluorfen (PoE $312.5 \mathrm{~g}$ a.i. ha- $\left.{ }^{-1}\right)\left(\mathrm{T}_{8}\right)$ being at par with propaquizafop + imazethapyr (PoE $125 \mathrm{~g}$ a.i. ha-1) $\left(\mathrm{T}_{5}\right)$ and hand weeding $\left(T_{9}\right)$ recorded significantly higher crop

Table 2: Density and dry matter of different categories of weeds in moth bean at harvest under different weed management practices (mean of three-year data) ${ }^{\mathrm{a}}$.

\begin{tabular}{|c|c|c|c|c|c|c|c|c|}
\hline \multirow{2}{*}{ Treatment } & \multicolumn{4}{|c|}{ Weed density (Nos. $\mathrm{m}^{-2}$ ) } & \multicolumn{4}{|c|}{ Weed dry matter $\left(\mathrm{g} \mathrm{m}^{-2}\right)$} \\
\hline & Grassy & Broad-leaved & Sedges & Total & Grassy & Broad-leaved & Sedges & Total \\
\hline $\mathrm{T}_{1}$ & $4.9^{\mathrm{de}}(23.7)$ & $3.7^{\mathrm{cd}}(13.3)$ & $2.5^{\text {cde }}(6.0)$ & $6.6^{\text {de }}(43.0)$ & $5.3^{\text {cd }}(28.1)$ & $9.8^{\mathrm{cd}}(97)$ & $3.4^{\mathrm{d}}(11.3)$ & $11.7^{\mathrm{d}}(136)$ \\
\hline $\mathrm{T}_{2}$ & $3.9^{b c}(15.0)$ & $3.3^{\mathrm{bcd}}(10.3)$ & $1.5^{b}(2.0)$ & $5.3^{\text {bc }}(27.3)$ & $4.4^{\mathrm{bc}}(19.0)$ & $6.5^{b}(45)$ & $2.1^{b}(3.8)$ & $8.1^{\mathrm{bc}}(68)$ \\
\hline $\mathrm{T}_{3}$ & $3.7^{\mathrm{bc}}(13.0)$ & $3.8^{\mathrm{cd}}(14.3)$ & $1.9^{\mathrm{bc}}(3.3)$ & $5.6^{\mathrm{bc}}(30.7)$ & $4.1^{b}(16.7)$ & $7.2^{b}(52)$ & $3.0^{\text {cd }}(8.7)$ & $8.8^{\mathrm{bc}}(77)$ \\
\hline $\mathrm{T}_{4}$ & $3.4^{\mathrm{b}}(11.3)$ & $3.0^{\mathrm{bc}}(8.3)$ & $2.8^{\text {de }}(7.7)$ & $5.3^{\text {bc }}(27.3)$ & $4.3^{\mathrm{bc}}(18.3)$ & $6.8^{b}(46)$ & $2.2^{\mathrm{b}}(4.2)$ & $8.3^{\mathrm{bc}}(68)$ \\
\hline $\mathrm{T}_{5}$ & $3.5^{\mathrm{b}}(11.7)$ & $2.5^{\mathrm{b}}(6.0)$ & $2.0^{\mathrm{bcd}}(3.7)$ & $4.7^{b}(21.3)$ & $4.1^{b}(16.0)$ & $6.4^{b}(40)$ & $2.4^{\mathrm{bc}}(5.2)$ & $7.9^{b}(62)$ \\
\hline $\mathrm{T}_{6}$ & $5.6^{\mathrm{e}}(31.0)$ & $4.2^{\text {cde }}(17.3)$ & $3.1^{e}(9.7)$ & $7.6^{f}(58.0)$ & $5.9^{d}(34.8)$ & $9.8^{\mathrm{cd}}(98)$ & $2.7^{\mathrm{bcd}}(6.7)$ & $11.8^{d}(139)$ \\
\hline $\mathrm{T}_{7}$ & $5.2^{\mathrm{de}}(27.0)$ & $4.3^{\text {de }}(17.7)$ & $1.8^{\mathrm{bc}}(3.0)$ & $6.9^{\text {ef }}(47.7)$ & $5.0^{\text {bcd }}(25.4)$ & $8.1^{\mathrm{bc}}(67)$ & $2.2^{\mathrm{b}}(4.3)$ & $9.8^{\mathrm{bc}}(97)$ \\
\hline $\mathrm{T}_{8}$ & $4.4^{\mathrm{cd}}(19.0)$ & $3.5^{\text {bcd }}(11.7)$ & $1.6^{b}(2.3)$ & $5.8^{\mathrm{cd}}(33.0)$ & $4.4^{\mathrm{bc}}(19.3)$ & $7.5^{b}(56)$ & $2.1^{b}(4.0)$ & $8.9^{\mathrm{bc}}(79)$ \\
\hline $\mathrm{T}_{9}$ & $3.3^{b}(10.7)$ & $3.5^{\mathrm{bcd}}(12.3)$ & $2.1^{\mathrm{bcd}}(4.0)$ & $5.2^{\mathrm{bc}}(27.0)$ & $4.1^{b}(16.3)$ & $6.4^{b}(40)$ & $3.1^{\mathrm{cd}}(9.0)$ & $8.1^{\mathrm{bc}}(66)$ \\
\hline$T_{10}$ & $8.2^{f}(67.7)$ & $5.1^{e}(27.3)$ & $3.0^{e}(8.7)$ & $10.2^{g}(103.7)$ & $9.2^{\mathrm{e}}(84.3)$ & $11.5^{d}(135)$ & $4.3^{e}(18.5)$ & $15.4^{e}(238)$ \\
\hline $\mathrm{T}_{11}$ & $0.7^{\mathrm{a}}(0.0)$ & $0.7^{\mathrm{a}}(0.0)$ & $0.7^{a}(0.0)$ & $0.7^{\mathrm{a}}(0.0)$ & $0.7^{\mathrm{a}}(0.0)$ & $0.7^{\mathrm{a}}(0.0)$ & $0.7^{\mathrm{a}}(0.0)$ & $0.7^{a}(0.0)$ \\
\hline
\end{tabular}

Treatment details are described in Table 1; Values in parentheses are the means of original values; Means (the square root transformed $(\sqrt{ } X+0.5)$ values) superscripted with different letters are significant at $p<0.05$ as per Tukey's HSD test. aValues against $T_{8}$ are the mean of two-year data.

Table 3: Crop phytotoxicity, growth and yield of moth bean as influenced by different weed management practices (mean of three-year data).

\begin{tabular}{|c|c|c|c|c|c|}
\hline \multirow{2}{*}{ Treatment } & \multicolumn{2}{|c|}{ Crop phytotoxicity visual rating score (10 DAT) } & \multirow{2}{*}{$\begin{array}{l}\text { Crop dry weight } \\
\qquad\left(\mathrm{g} \mathrm{m}^{-2}\right)\end{array}$} & \multirow{2}{*}{$\begin{array}{l}\text { Grain yield } \\
\qquad\left(\mathrm{q} \mathrm{ha} \mathrm{h}^{-1}\right)\end{array}$} & \multirow{2}{*}{$\begin{array}{l}\text { Stover yield } \\
\quad\left(\mathrm{q} \mathrm{ha}^{-1}\right)\end{array}$} \\
\hline & Score & Effect on crop & & & \\
\hline $\mathrm{T}_{1}$ & 0 & No injury & $478^{\mathrm{bc}}$ & $4.40^{\mathrm{bc}}$ & $12.5^{\mathrm{ab}}$ \\
\hline $\mathrm{T}_{2}$ & 1 & Slight stunting, discoloration & $406^{b}$ & $4.36^{\mathrm{bc}}$ & $13.3^{\mathrm{bcd}}$ \\
\hline $\mathrm{T}_{3}$ & 1 & Slight stunting, discoloration & $444^{\mathrm{bc}}$ & $4.53^{\mathrm{bc}}$ & $13.6^{\mathrm{bcd}}$ \\
\hline $\mathrm{T}_{4}$ & 1 & Slight stunting, discoloration & $473^{\mathrm{bc}}$ & $4.20^{\mathrm{b}}$ & $15.3^{\text {de }}$ \\
\hline $\mathrm{T}_{5}$ & 2 & Stunting and discoloration & $450^{\mathrm{bc}}$ & $4.29^{b}$ & $20.0^{f}$ \\
\hline $\mathrm{T}_{6}$ & 0 & No injury & $413^{b}$ & $4.71^{\mathrm{bd}}$ & $11.7^{\mathrm{bc}}$ \\
\hline $\mathrm{T}_{7}$ & 0 & No injury & $439^{\mathrm{bc}}$ & $5.21^{\text {cde }}$ & $14.2^{\mathrm{cd}}$ \\
\hline $\mathrm{T}_{8}$ & 0 & No injury & $513^{c}$ & $5.53^{\mathrm{de}}$ & $18.0^{\text {ef }}$ \\
\hline $\mathrm{T}_{9}$ & & & $519^{c}$ & $5.87^{e}$ & $19.3^{f}$ \\
\hline $\mathrm{T}_{10}$ & & & $327^{a}$ & $3.40^{\mathrm{a}}$ & $10.0^{\mathrm{a}}$ \\
\hline $\mathrm{T}_{11}$ & & & $613^{d}$ & $6.92^{f}$ & $23.9^{9}$ \\
\hline
\end{tabular}

Treatment details are described in Table 1; Means superscripted with different letters are significant at $p<0.05$ as per Tukey's HSD test; NS- Non-significant; aValues against $\mathrm{T}_{8}$ are mean of two-year data. 
Bioefficacy, Phytotoxicity and Economics of Post-emergence Herbicides in Moth Bean (Vigna aconitifolia) in Hot Arid Regions

Table 4: Economics of different weed management practices in moth bean (mean of three-year data).

\begin{tabular}{|c|c|c|c|c|c|c|c|}
\hline Treatment & $\begin{array}{l}{ }^{*} \text { Gross } \\
\text { returns } \\
(\text { Rs. ha-1) } \\
\text { (a) }\end{array}$ & $\begin{array}{c}\text { Cost of } \\
\text { herbicide } \\
\left(\text { Rs. ha }{ }^{-1}\right) \\
\text { (b) }\end{array}$ & $\begin{array}{l}\text { Sprayer } \\
\text { rent } \\
\left(\text { Rs. ha }^{-1}\right) \\
\text { (c) }\end{array}$ & $\begin{array}{c}{ }^{* *} \text { Labour } \\
\text { cost } \\
\left(\text { Rs. ha }{ }^{-1}\right) \\
\text { (d) }\end{array}$ & $\begin{array}{c}\text { Total variable } \\
\text { cost } \\
\left(\text { Rs. ha }{ }^{-1}\right) \\
e=(b+c+d)\end{array}$ & $\begin{array}{l}{ }^{* *} \text { Total cost of } \\
\text { cultivation } \\
\left(\text { Rs. ha }{ }^{-1}\right) \\
\text { (Rs. } 9000+\text { d) }\end{array}$ & $\begin{array}{c}\text { Net } \\
\text { benefit } \\
\left(\text { Rs. ha- }{ }^{-1}\right) \\
(a-e)\end{array}$ \\
\hline $\mathrm{T}_{1}$ & 19880 & 1193 & 500 & 600 & 2293 & 11293 & 17587 \\
\hline $\mathrm{T}_{2}$ & 20571 & 600 & 500 & 600 & 1700 & 10700 & 18871 \\
\hline $\mathrm{T}_{3}$ & 21295 & 1550 & 500 & 600 & 2650 & 11650 & 18645 \\
\hline $\mathrm{T}_{4}$ & 20548 & 1600 & 500 & 600 & 2700 & 11700 & 17848 \\
\hline $\mathrm{T}_{5}$ & 22298 & 2000 & 500 & 600 & 3100 & 12100 & 19198 \\
\hline $\mathrm{T}_{6}$ & 21408 & 1071 & 500 & 600 & 2171 & 11171 & 19237 \\
\hline $\mathrm{T}_{7}$ & 24051 & 1400 & 500 & 600 & 2500 & 11500 & 21551 \\
\hline $\mathrm{T}_{8}$ & 26421 & 1786 & 500 & 600 & 2886 & 11886 & 23535 \\
\hline $\mathrm{T}_{9}$ & 28071 & 0 & 0 & 3000 & 3000 & 12000 & 25071 \\
\hline $\mathrm{T}_{10}$ & 11539 & 0 & 0 & 0 & 0 & 9000 & 11539 \\
\hline $\mathrm{T}_{11}$ & 33465 & 0 & 0 & 6000 & 6000 & 15000 & 27465 \\
\hline
\end{tabular}

*Seed price @ Rs $3800 \mathrm{q}^{-1}$; stover price @ Rs $200 \mathrm{q}^{-1}$; ${ }^{* *}$ Labour cost @ Rs. 300 man day ${ }^{1}$; ${ }^{* * *}$ Cost of cultivation of moth bean except weed management- Rs. 9000 ha $^{-1}$, aValues against $\mathrm{T}_{8}$ are mean of two years data.

dry weight $\left(513 \mathrm{~g} \mathrm{~m}^{-2}\right)$. Thus, the variation in crop dry weight under different herbicides was ascribed both due to effective weed control and the phytotoxic effect of imazethapyr on moth bean. The significant difference in crop growth under the different magnitude of crop-weed interference resulted in significant differences in the yields of moth bean (Table 3). On the other hand, the favourable environment provided due to the higher weed control efficacy of imazethapyrcontaining treatments $\left(T_{2}, T_{3}, T_{4}\right.$ and $\left.T_{5}\right)$ was suppressed by the phytotoxic effect on moth bean and it was manifested in the growth and yield of the crop.

Because of its at par weed control efficacy and no phytotoxic effect on moth bean, clodinafop-propargyl + sodium acifluorfen (PoE $312.5 \mathrm{~g}$ a.i. ha $\left.{ }^{-1}\right)\left(\mathrm{T}_{8}\right)$ being at per with hand weeding $\left(T_{9}\right)$, recorded significantly higher seed yield (5.53 q ha-1) over imazethapyr containing treatments $\left(T_{2}, T_{3}, T_{4}\right.$ and $\left.T_{5}\right)$ and pendimethalin $\left(T_{1}\right)$. However, in terms of stover yield, clodinafop-propargyl + sodium acifluorfen

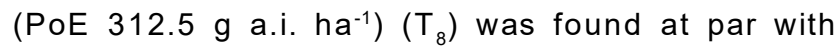
propaquizafop + imazethapyr (PoE $125 \mathrm{~g}$ a.i. ha-1) $\left(\mathrm{T}_{5}\right)$ and hand weeding $\left(T_{9}\right)$. The higher yield under these treatments might be due to effective control of the weeds as indicated through higher WCE. Clodinafop-propargyl + sodium acifluorfen (PoE $312.5 \mathrm{~g}$ a.i. ha $\left.{ }^{-1}\right)\left(\mathrm{T}_{8}\right)$ produced $162.4 \%$ and $180.0 \%$ higher seed yield and stover yield over unweeded, respectively. In this study, weed competition and crop phytotoxicity have manifested in crop growth and yields.

\section{Economics}

The higher seed and stover yield recorded under weed-free $\left(T_{11}\right)$ treatment resulted in the highest gross returns and net benefits of moth bean, which was closely followed by hand weeding $\left(T_{9}\right)$ (Table 4$)$. These results corroborated with the finding of Ram Pratap et al. (2018). The weed management in moth bean, either through hand weeding or effective PoE herbicides $\left(T_{8}\right)$, accounts for around $24-25 \%$ of the cost of
Table 5: Impact assessment indices of herbicide treatments.

\begin{tabular}{lccccc}
\hline Treatment & WCE $(\%)$ & WI & HEI & WPI & CRI \\
\hline $\mathrm{T}_{1}$ & 40.8 & 36 & 1.5 & 1.38 & 2.55 \\
$\mathrm{~T}_{2}$ & 69.4 & 37 & 2.9 & 1.04 & 4.36 \\
$\mathrm{~T}_{3}$ & 67.6 & 34 & 2.7 & 1.06 & 4.2 \\
$\mathrm{~T}_{4}$ & 71 & 39 & 2.6 & 1.08 & 4.05 \\
$\mathrm{~T}_{5}$ & 73.8 & 38 & 3.0 & 1.03 & 4.31 \\
$\mathrm{~T}_{6}$ & 41.4 & 32 & 1.6 & 1.09 & 2.16 \\
$\mathrm{~T}_{7}$ & 59.7 & 25 & 2.9 & 1.08 & 3.3 \\
$\mathrm{~T}_{8}$ & 66.3 & 20 & 3.9 & 1.05 & 4.7 \\
$\mathrm{~T}_{9}$ & 71.9 & 15 & - & - & - \\
$\mathrm{T}_{10}$ & 0 & 65 & - & - & - \\
$\mathrm{T}_{11}$ & 100 & - & - & - & - \\
\hline
\end{tabular}

Treatment details are described in Table 1.

cultivation. Although imazethapyr-containing herbicides $\left(T_{2}\right.$, $T_{3}, T_{4}$ and $T_{5}$ ) have been more effective on weeds, as evidenced through WCE (Table 5), their crop phytotoxic effect resulted in low yields, therefore, low gross returns and net benefit. Thus, the highest gross returns (Rs. 26421 ha $^{-1}$ ) and net benefits (Rs. 23535 ha $^{-1}$ ) of moth bean were recorded under clodinafop-propargyl + sodium acifluorfen (PoE $312.5 \mathrm{~g}$ a.i. ha $\left.{ }^{-1}\right)\left(\mathrm{T}_{8}\right)$.

\section{Impact assessment indices}

The significant difference in weed dry matter in different weed management practices was manifested in WCE and WI (Table 5). The better control of both grassy and broad-leaved weed under propaquizafop + imazethapyr (PoE $125 \mathrm{~g}$ a.i. ha $\left.^{-1}\right)\left(T_{5}\right)$ results in the highest WCE (73.8\%). However, due to the crop phytotoxic effect of imazethapyr, the minimum value of WI (20) was recorded in clodinafop-propargyl + sodium acifluorfen (PoE $312.5 \mathrm{~g}$ a.i. $\mathrm{ha}^{-1}$ ) $\left(\mathrm{T}_{8}\right)$. It reflects the effectiveness of applied herbicide in securing yield loss against weed competition and a lower value of WI means high herbicide efficiency. 
As for efficient weed management, lower WPI and higher HEI values are desirable. Clodinafop-propargyl + sodium acifluorfen (PoE $312.5 \mathrm{~g}$ a.i. ha-1) $\left(\mathrm{T}_{8}\right)$ recorded the highest HEI (3.9), indicating the higher yield advantage (Table 5). The lowest WPI was recorded in propaquizafop + imazethapyr (PoE $125 \mathrm{~g}$ a.i. ha $\left.{ }^{-1}\right)\left(\mathrm{T}_{10}\right)(1.03)$. The highest CRI (4.70) was recorded in clodinafop-propargyl + sodium acifluorfen (PoE $312.5 \mathrm{~g}$ a.i. ha-1) $\left(\mathrm{T}_{8}\right)$. This might have been due to satisfactory weed control under this treatment and no phytotoxic effect on the crop. These results corroborate the findings of Kumar et al. (2018).

\section{CONCLUSION}

The promising herbicides molecule for post-emergence application in Kharif pulses like imazethapyr causes phytotoxicity to moth bean resulted in lower yield and economic returns. Alternatively, post-emergence application of clodinafop-propargyl + sodium acifluorfen @ $312.5 \mathrm{~g}$ a.i. ha $^{-1}$ was found to manage weed spectrum on par with imazethapyr herbicides and recorded significantly higher crop growth, yield and net benefits of moth bean in western arid regions of India.

\section{REFERENCES}

Harithavardhini, J., Jayalalitha, K., Ashoka Rani, Y. and Krishnaveni, B. (2016). Efficacy of post emergence herbicides on weed control efficiency, partitioning of dry matter and yield of blackgram [Vigna mungo (L.) Hepper]. International Journal of Food, Agriculture and Veterinary Sciences. 6(2): 39-44.

Jat, H.L., Singh, P. and Lakhera, J.P. (2011). Constraints in adoption of moth bean production technology in arid zone of Rajasthan. Rajasthan Journal of Extension Education. 19: 185-189.

Khairnar, C.B., Goud, V.V. and Sethi, H.N. (2014). Pre and postemergence herbicides for weed management in mung bean. Indian Journal of Weed Science. 46(4): 392-395.

Kumar, S., Rana, M.C. and Rana, S.S. (2018). Impact of propaquizafop on weed growth, yield and economics of soybean (Glycine max L.) under mid hill conditions of Himachal Pradesh. Journal of Pharmacognosy and Phytochemistry. 7(6): 650-654.
Mani, V.S., Malla, M.C., Gautam, K.C. and Bhagwant, S. (1973). Weed killing chemicals in potato cultivars. Indian Farming. 32: 17-18.

Patel, B.J., Patel, H.H. and Ganvit, V.C. (2019). Effect of spacing and weed management on yield, quality and nutrient uptake of moth bean (Vigna aconitifolia). Journal of Pharmacognosy and Phytochemistry. 8(5): 948-952.

Punia, S.S., Singh, S. and Yadav, D. (2011). Bioefficacy of imazethapyr and chlorimuron-ethyl in clusterbean and their residual effect on succeeding Rabi crops. Indian Journal of Weed Science. 43(1 and 2): 48-53.

Punia, S.S., Yadav, D., Duhan, A. and Mohammad, I. (2015). Bioefficacy and phytotoxicity of herbicides in greengram and their residual effect on succeeding mustard. Indian Journal of Weed Science. 47(4): 386-489.

Ram, P., Singh, S.P., Yadav, R.S. and Kumawat, A. (2018). Efficacy of herbicides for control of weeds in moth bean. Indian Journal of Weed Science. 50(1): 88-90.

Rao, V.S. (2000). Principles of Weed Science. Oxford and IBH Publishing Co. Pvt. Ltd., New Delhi.

Saltoni, N., Shropshire, C., Cowan, T. and Sikkema, P. (2004). Tolerance of black beans (Phaseolus vulgaris) to soil application of s-metalochlor and imazethapyr. Weed Technology. 18: 111-118.

Saxena, A., Singh, Y.V., Singh, D.V. and Singh, R. (2003). Weed management in moth bean (Vigna aconitifolia) in arid region of Rajasthan. Annals of Arid Zone. 42(2): 137140.

Sen, S., Kaur, R. and Das, T.K. (2020). Weed management in dry direct-seeded rice: Assessing the impacts on weeds and crop. Indian Journal of Weed Science. 52(2): 169-174.

Singh, S.P., Yadav, R.S. and Sharma, V. (2016). Weed control in clusterbean through post-emergence herbicides. Indian Journal of Weed Science. 48(2): 202-205.

SPSS for Windows, Version 16.0. Chicago, SPSS Inc; 2007.

Upadhayay, V.B., Singh, A. and Rawat, A. (2013). Efficacy of early post-emergence herbicides against associated weeds in soybean. Indian Journal of Weed Science. 44(40): 73-75. 